\title{
Impact of RSETI Trainings on Entrepreneurship Development
}

\author{
Amandeep Kaur Makkar* and Sukhdeep Kaur Mann \\ Department of Extension Education and Communication Management, PAU, Ludhiana, India \\ *Corresponding author
}

Keywords

RSETI, Self

employment,

Youth, BPL,

Entrepreneurship

Article Info

Accepted:

10 July 2020

Available Online:

10 August 2020

\begin{abstract}
A B S T R A C T
Rural Self Employment Training Institute (RSETI) is a replicated model of Rural

Development and Self Employment Training Institute (RUDSETI) and a unique initiative which not only imparts training to the rural youths for different economic activities but also extends supports to beneficiaries to settle through self-employment by providing credit linkage to the beneficiaries. To see the impact of RSETI trainings on the beneficiaries of Ludhiana district a study was conducted with the objective to find out the rate of settlement, time taken to establish the enterprise and role of RSETI in supporting the trained candidates in the settlement process. Data was collected through personal interview method from the beneficiaries who took training during the year 2012-14 and were engaged in different entrepreneurial activities. Finding of the study states that majority of the respondents were already engaged in entrepreneurial activities before the training programme and only the $33 \%$ of the beneficiaries established new enterprise after taking training from RSETI. Fifty percent of the beneficiaries started their enterprise within six months of the completion of training programme and took loan from commercial/cooperative banks were the major source of financial output.
\end{abstract}

\section{Introduction}

Unemployment is the prime challenge India is facing in the process of its development and inclusive growth. Millions of unemployed youth, particularly from rural and semi-urban areas, who could not access higher/ professional education but are oriented towards white collar jobs are driven to despair for want of job opportunities. Of late, these distressed youth are attracted towards many anti-social activities in the urban areas for their livelihood. This tremendous pressure on civic life in urban areas along with mismatch of potential for productive deployment has baffled the planners and administrators. All this clearly indicates the need for promoting self employment and entrepreneurial ventures among the unemployed youth, PSB - RSETI has established in 2009 in Ludhiana district of Punjab state with the objective to train the unemployed youth to take up wage employment as a source of livelihood. It mainly provides handholding support for establishing and successful running of an enterprise such as linkages with banks for financial assistance and also promotes project consultancy services and counseling and develops confidence in unemployed youth. Punjab and Sind Bank is the lead bank in the 
district takes responsibility for managing it. From this study researcher has find out a reliable source for unemployed youth to start their career with self employment. PSB RSETI Ludhiana gives them a special assistant for set up their ventures.

The main objective of this study includes to study the impact of RSETI training in establishment of an enterprise.

\section{Materials and Methods}

The current study is based on the data gathered from the primary sources (interactions with the Institute). The study was conducted in purposively selected Ludhiana district of Punjab state. During the year 2012-14, a list of beneficiaries who had taken any type of EDP training, was procured from the PSB - RSETI, Ludhiana. Of the total trainees listed (800), a random sample of 20 per cent trainees were selected. Thus, 150 trainees formed the sample unit for the study. Data was analysis with the help of different statistical tools such as percentages, frequencies.

\section{Results and Discussion}

Engagement in income generation activity before getting training at RSETI

Table 1 illustrates the distribution of beneficiaries on the basis of prior engagement in some income generation activity before getting training at RSETI. It was interesting to note that 74 per cent of total beneficiaries under study were engaged in some income generation activity before getting training at RSETI. The reason behind the high percentage of beneficiaries being prior engaged in some activity, opted to be RSETI beneficiaries may be due to under employment and seasonal unemployment. They also wanted to establish their own business through which permanent nature of employment can he generated throughout the year. Further, analysis of table shows that more than 80 per cent of beneficiaries in agricultural $(86.66 \%)$, product $(86.84 \%)$ and process EDPs $(82.25 \%)$ were engaged in some income generation activity. So, it can be concluded that only 26 per cent of beneficiaries were unemployed before attending RSETI training. Similar findings were also reported by Ramakrishnan (2004).

\section{Establishment of new / expansion of an enterprise}

The data in Fig 1 indicates that majority of beneficiaries (66.66\%) had expanded the previous enterprise while 33.33 per cent had established the new enterprise after attending trainings at RSETI. The data in table 4 reveals that most of the beneficiaries in agricultural EDPs $(66.66 \%)$, product EDPs $(78.94 \%)$, process EDPs $(75.80 \%)$ and other EDPs $(69.23 \%)$ had expanded their previous enterprise. Whereas, in general EDPs majority of beneficiaries $(81.81 \%)$ had established the new enterprise. In contradiction, the findings of Mamata and Renuka (2012) reported that majority of the women $(43.40 \%)$ had started new enterprise after undergoing training.

\section{Time lag in establishing an enterprise after training programme}

The data incorporated in table 3 shows the distribution of beneficiaries according to the time lag in establishing an enterprise after the completion of training programme. The table clearly shows that 50 per cent of beneficiaries started their respective enterprise within six months of completion of the training programme and 20 per cent of the beneficiaries started their enterprise after one year of subsequently completion of the training programme. In agricultural EDPs, 60 per cent beneficiaries took more than 12 months to start their enterprise after the completion of training followed by 40 per 
cent beneficiaries who took 7 to 12 months in establishing an enterprise. The reason given for delay in setting up an enterprise was hindrance in sanctioning of the loan. Majority of the beneficiaries in product (50\%), process (53\%) and general EDPs (72.72\%) started their enterprise within six months after taking the training from RSETI. In other EDPs, similar percentage of beneficiaries took 7 to 12 months and more than 12 months (50\%) in establishing an enterprise.
The findings are similar with Kumar (2016), he revealed that majority $(51.02 \%)$ of the trainees started their enterprise within six months after taking the training from the institute. Whereas, 34.69 per cent of the trainees took 7 to 12 months to start their units and only 14.29 per cent of the trainees took more than 12 months to start their enterprise.

Table.1 Engagement in income generation activity before getting training at RSETI

\begin{tabular}{|c|c|c|c|c|c|c|}
\hline \multirow{2}{*}{ Category } & \multicolumn{7}{|c|}{ Type of training programme } & \\
\cline { 2 - 8 } & $\begin{array}{c}\text { Agricultural EDPs } \\
(\mathbf{n = 1 5})\end{array}$ & $\begin{array}{c}\text { Product EDPs } \\
(\mathbf{n = 3 8})\end{array}$ & $\begin{array}{c}\text { Process EDPs } \\
(\mathbf{n = 6 2})\end{array}$ & $\begin{array}{c}\text { General EDPs } \\
(\mathbf{n = 2 2})\end{array}$ & $\begin{array}{c}\text { Other EDPs } \\
(\mathbf{n = 1 3})\end{array}$ & $\begin{array}{c}\text { Total } \\
(\mathbf{n = 1 5 0})\end{array}$ \\
\hline Engaged & 13 & 33 & 51 & 05 & 09 & 111 \\
& $(86.66)$ & $(86.84)$ & $(82.25)$ & $(22.72)$ & $(69.23)$ & $(74)$ \\
\hline
\end{tabular}

(Figure in parenthesis denotes percentage)

Table.2 Distribution of beneficiaries on the basis of establishment of new / expansion of an enterprise after training programme

\begin{tabular}{|l|c|c|c|c|c|c|}
\hline \multirow{2}{*}{ Categories } & \multicolumn{7}{|c|}{ Type of training programme } \\
\cline { 2 - 7 } & $\begin{array}{c}\text { Agricultural EDPs } \\
(\mathbf{n = 1 5 )}\end{array}$ & $\begin{array}{c}\text { Product } \\
\text { EDPs(n=38) }\end{array}$ & $\begin{array}{c}\text { Process EDPs } \\
(\mathbf{n = 6 2 )}\end{array}$ & $\begin{array}{c}\text { General } \\
\text { EDPs (n=22) }\end{array}$ & $\begin{array}{c}\text { Other EDPs } \\
(\mathbf{n = 1 3})\end{array}$ & $\begin{array}{c}\text { Total } \\
(\mathbf{n = 1 5 0})\end{array}$ \\
\hline $\begin{array}{l}\text { Established new } \\
\text { enterprise }\end{array}$ & 05 & 08 & 15 & 18 & 04 & 50 \\
\hline $\begin{array}{l}\text { Expanded } \\
\text { previous } \\
\text { enterprise }\end{array}$ & $(33.33)$ & $(21.05)$ & $(24.19)$ & $(81.81)$ & $(30.76)$ & $(33.33)$ \\
\hline
\end{tabular}

(Figure in parenthesis denotes percentage)

Table.3 Distribution of beneficiaries according to the time lag in establishing an enterprise after training programme

\begin{tabular}{|c|c|c|c|c|c|c|}
\hline \multirow{2}{*}{ Time Lag } & \multicolumn{7}{|c|}{ Type of training programme } & \multicolumn{1}{|c|}{ Total } \\
\cline { 2 - 6 } & $\begin{array}{c}\text { Agricultural } \\
\text { EDPs (n=5) }\end{array}$ & $\begin{array}{c}\text { Product EDPs } \\
(\mathbf{n = 8})\end{array}$ & $\begin{array}{c}\text { Process EDPs } \\
(\mathbf{n = 1 5})\end{array}$ & $\begin{array}{c}\text { General EDPs } \\
(\mathbf{n = 1 8})\end{array}$ & $\begin{array}{c}\text { Other } \\
\text { EDPs(n=4) }\end{array}$ \\
\hline Low & --- & 04 & 08 & 13 & -- & 25 \\
(Up to 6 months) & & $(50)$ & $(53.33)$ & $(72.22)$ & $(50)$ \\
\hline Medium & 02 & 02 & 04 & 05 & 02 & 15 \\
(Up to 7-12 months) & $(40)$ & $(25)$ & $(26.66)$ & $(27.77)$ & $(50)$ & $(30)$ \\
\hline High & 03 & 02 & 03 & --- & 02 & 10 \\
(More than 12 months) & $(60)$ & $(25)$ & $(20)$ & & $(50)$ & $(20)$ \\
\hline
\end{tabular}

(Figure in parenthesis denotes percentage) 
Table.4 Distribution of beneficiaries according to source of financial inputs for starting / expanding an enterprise

\begin{tabular}{|c|c|c|c|c|c|c|}
\hline \multirow{2}{*}{$\begin{array}{l}\text { Sources of } \\
\text { investment }\end{array}$} & \multicolumn{5}{|c|}{ Type of training programme } & \multirow{2}{*}{$\begin{array}{c}\text { Total } \\
(n=150)\end{array}$} \\
\hline & $\begin{array}{l}\text { Agricultural } \\
\text { EDPs }(n=15)\end{array}$ & $\begin{array}{c}\text { Product } \\
\text { EDPs } \\
(n=38)\end{array}$ & $\begin{array}{c}\text { Process } \\
\text { EDPs } \\
(n=62)\end{array}$ & $\begin{array}{l}\text { General EDPs } \\
\qquad(n=22)\end{array}$ & $\begin{array}{c}\text { Other } \\
\text { EDPs } \\
(n=13)\end{array}$ & \\
\hline \multicolumn{7}{|l|}{ Savings } \\
\hline $\begin{array}{l}\text { Personal and family } \\
\text { savings }\end{array}$ & $\begin{array}{c}10 \\
(66.66)\end{array}$ & $\begin{array}{c}22 \\
(57.89)\end{array}$ & $\begin{array}{c}28 \\
(45.16)\end{array}$ & $\begin{array}{c}15 \\
(68.18)\end{array}$ & $\begin{array}{c}05 \\
(38.46)\end{array}$ & $\begin{array}{c}80 \\
(53.33)\end{array}$ \\
\hline \multicolumn{7}{|l|}{ Loan } \\
\hline $\begin{array}{l}\text { Friends and } \\
\text { relatives }\end{array}$ & $\begin{array}{c}03 \\
(20)\end{array}$ & $\begin{array}{c}10 \\
(26.31)\end{array}$ & $\begin{array}{c}16 \\
(25.80)\end{array}$ & $\begin{array}{c}04 \\
(18.18)\end{array}$ & $\begin{array}{c}06 \\
(46.15)\end{array}$ & $\begin{array}{c}39 \\
(26)\end{array}$ \\
\hline $\begin{array}{l}\text { Commercial/ } \\
\text { Cooperative banks }\end{array}$ & $\begin{array}{c}15 \\
(100)\end{array}$ & $\begin{array}{c}25 \\
(65.78)\end{array}$ & $\begin{array}{c}55 \\
(88.70)\end{array}$ & $\begin{array}{c}12 \\
(54.54)\end{array}$ & $\begin{array}{c}13 \\
(100)\end{array}$ & $\begin{array}{l}120 \\
(80)\end{array}$ \\
\hline Money lenders & $\begin{array}{c}07 \\
(46.66)\end{array}$ & $\begin{array}{c}11 \\
(28.94)\end{array}$ & $\begin{array}{c}14 \\
(22.58)\end{array}$ & $\begin{array}{c}03 \\
(13.63)\end{array}$ & $\begin{array}{c}03 \\
(23.07)\end{array}$ & $\begin{array}{c}38 \\
(25.33)\end{array}$ \\
\hline
\end{tabular}

Multiple response

(Figure in parenthesis denotes percentage)

Fig.1 Distribution of respondents on the basis of establishment of new / expansion of an enterprise by beneficiaries after training programme

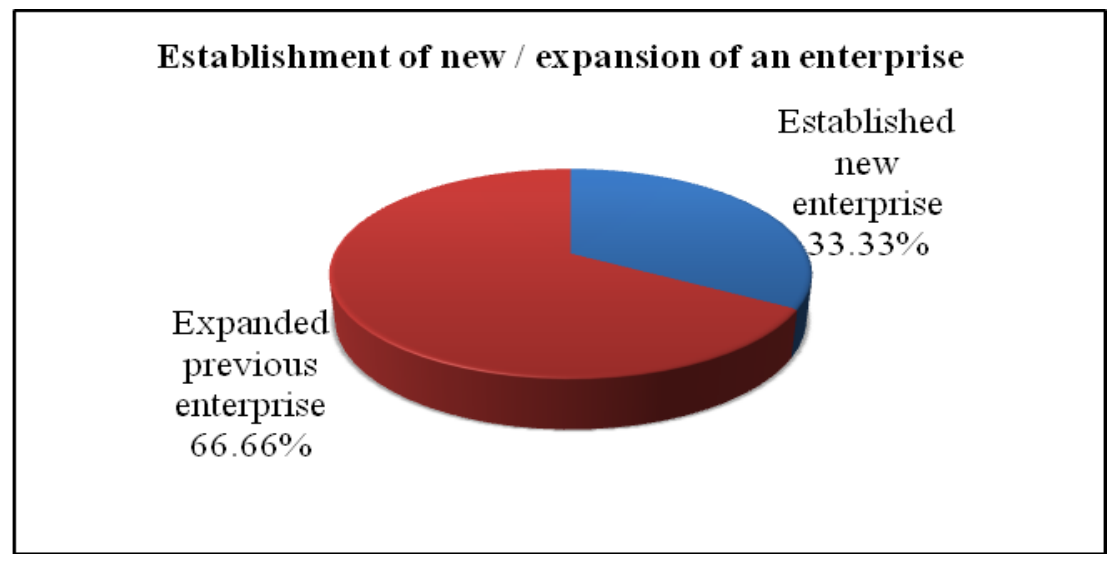

Source of financial inputs for from money lenders. Whereas, 53. 33 per cent starting/expanding an enterprise of beneficiaries had invested their personal and family savings.

Table 4 discusses the sources of financial inputs for starting/ expanding an enterprise. Two sources mainly savings and loans were reported by the beneficiaries. Perusal of data indicates that 80 per cent of beneficiaries took loan from the commercial/cooperative banks and 25.33 per cent of beneficiaries took loan

Further table depicts that in agricultural EDPs, 100 per cent of beneficiaries took loan from commercial/cooperative banks. More than 40 per cent of beneficiaries $(46.66 \%)$ had taken up loan from money lenders in agricultural EDPs while least number of 
beneficiaries (13.63\%) from general EDPs were found in this category. Majority of beneficiaries (68.18\%) from general EDPs had invested from personal and family savings to start their enterprise. In other EDPs, 46.15 per cent of beneficiaries had taken up the loan from friends and relatives. The findings are in contrary with the results reported by Rajendran (2002), Honakeri (2002), Gangaiah et al., (2006) and Sushma (2007).

In conclusion it has been observed that RSETI trainings are having huge scope for the unemployed youths who are interested in selfemployment. After interaction with the members of RSETI who were trained by RSETI officials revealed that they were satisfied after the training and most of the beneficiaries had expanded their previous enterprise and less number of beneficiaries were engaged in new enterprise. Majority of the beneficiaries took loan from the banks for establishment of an enterprise. So, it can be concluded that RSETI should encourage rural youth to initiate entrepreneurship through skill development trainings.

\section{References}

Gangaiah, G, Nagaraja, B and Naidu, C (2006) Impact of self help groups on income and employment: A case study. Kurukshetra 54: 18-23.

Honakeri, P. M. (2002) Financing of small scale automobile and hardware retail entrepreneurship: A case study. Southern Economics 41: 20-21.

Mamata, B. and Renuka, T. (2012) Role of RUDSETI in empowering women through entrepreneurship - A study of Bijapur district. International Journal of Economics, Business and Entrepreneurship 1: 208-22

Rajendran, G. (2002) A study on the entrepreneurial development in Andaman and Nicobar Islands. Small Enterprise Development and Management Extension 29(4): 61-67.

Ramkrishn, B. (2004) An analysis of self employment generation for educated unemployed youth through Prime Minister's Rojgar Yojna in Udaipur district of Rajasthan, Ph.D. Dissertation, Maharana Pratap University of Agriculture and Technology, Udaipur, India.

Sushma, K. C. (2007) An analysis of entrepreneurship development in women through EDP trainings, M.Sc. (Agri.) Thesis, University of Agricultural Sciences, Dharwad, India.

\section{How to cite this article:}

Amandeep Kaur Makkar and Sukhdeep Kaur Mann. 2020. Impact of RSETI Trainings on Entrepreneurship Development. Int.J.Curr.Microbiol.App.Sci. 9(08): 854-858. doi: https://doi.org/10.20546/ijcmas.2020.908.092 